\title{
Parenting Style and Community Relationship Pattern in Tanjungpinang City in the Context of Chinese New Year Celebrations Two Months Before the COVID-19 Pandemic in Indonesia
}

\author{
Maitri Widya Mutiara $^{1,2^{*}}$, Mariati ${ }^{1,2}$, Jap Tji Beng ${ }^{1,3}$, Sri Tiatri ${ }^{1,4}$ \\ ${ }^{1}$ Center for Chinese Indonesian Studies, Universitas Tarumanagara, Jakarta 11450, Indonesia \\ ${ }^{2}$ Faculty of Visual Art and Design, Universitas Tarumanagara, Jakarta 11450, Indonesia \\ ${ }^{3}$ Faculty of Information Technology, Universitas Tarumanagara, Jakarta 11450, Indonesia \\ ${ }^{4}$ Faculty of Psychology, Universitas Tarumanagara, Jakarta 11450, Indonesia \\ *Corresponding author. Email: maitrim@fsrd.untar.ac.id,
}

\begin{abstract}
Tanjungpinang is a city within an archipelago with a unique geographical structure and composition of the population. The COVID-19 pandemic brought about a change in behavior in most communities. This study aims to provide an overview of parenting style and relationship patterns of the Chinese community in Tanjungpinang, in the context of Chinese New Year celebrations, which were conducted exactly two months before the COVID-19 Pandemic. Participants of this study were 5 families living in Tanjungpinang, as well as the community that was involved in the Chinese New Year celebration. The study was conducted using a qualitative method, and an ethnographic approach. Data collection was conducted through observation and in-depth interviews. The study shows that although different, the parenting style of the five families tend to be authoritative. Relationships between community members tend to be formal and not intimate. However, there is strong mutual respect among community members. Gadget usage is high among the younger generation, and this can affect social awareness. The use of gadgets by the younger generation is expected to become more prevalent during the COVID-19 pandemic. The findings show the influence of community context on family and individual behavior in Tanjungpinang, and this supports the ecological theory by Bronfenbrenner.
\end{abstract}

Keywords: parenting style, community relationship pattern, parents, Chinese New Year

\section{INTRODUCTION}

Based on the information on the website of Tanjungpinang city government website (retrieved: 2019, January 15), Kota Tanjungpinang is a city within an archipelago with a unique geographical structure and population composition. Tanjungpinang is the capital of the Riau Islands Province. Geographically, Tanjungpinang City is adjacent to Batam City and borders Singapore. This makes Tanjungpinang City a strategic city. In terms of population, the inhabitants of Tanjungpinang City consist of various kinds of ethnic groups, including: (a) Malays (as indigenous / local residents); (b) Batak; (c) Minang; (d) Javanese; (e) Bugis; and (f) Chinese. Even so, diversity has become a part of everyday life in the Tanjungpinang community. Other cultures besides the Malay Culture have also experienced development while respecting the Malay culture as the original culture [1].
The Tanjungpinang city government website (retrieved: 2019, January 15) stated that one of the cultures that has developed is Chinese culture. Every year, before the Chinese New Year celebration in Tanjungpinang City the "Chinese New Year Bazaar" is always being held. This bazaar is one of the annual agendas that is held to preserve and introduce Chinese ethnic culture to the Indonesian people [2]. According to the Mayor of Tanjungpinang, this event shows cohesiveness, togetherness and the spirit of unity and integrity in the City of Tanjungpinang [3].

This celebration also shows that there is a large Chinese population in Tanjungpinang City, and the quite extensive history of the Chinese community in Tanjungpinang. This is evidenced by the existence of the oldest pagoda in Senggarang (built around the 17th century). In addition, there are various Chinese tribes in Tanjungpinang such as the Hokkien, Cantonese, and Tio Ciu. The Chinese community plays an active role in various aspects of life in Tanjungpinang. One example is in the economy. The 
majority of the Tanjungpinang economy is driven by the Chinese ethnic community. In addition, there are Chinese people in Tanjungpinang who serve as politicians, people's representatives, and political figures [4].

This research is a series of studies on Chinese culture in several cities in Indonesia. This research was conducted mainly to examine the role of Chinese culture in the life of society and their state in Indonesia. The research team tried to uncover this through the parenting style and community relationship pattern among Three Generations of the Chinese community in Tanjungpinang.

Parenting style is a concept put forward by Diana Baumrind based on the results of her research on the behavior patterns of children raised by their parents. There are four types of parenting styles, namely: (a) authoritative parenting, (b) permissive parenting, (c) neglected parenting, and (d) authoritarian parenting [5]. Parents play an important role in fostering positive development in adolescents. Research results showed that there are consistent and strong associations between parenting style and a wide range of outcomes in adolescents, including subjective well-being and self-esteem, health and risky behavior, and school result and enrolment [6].

This research also attempted to see the role of community relationship patterns in Chinese community in Tanjungpinang. Based on a literature [7], there are two types of groups, namely formal groups and informal groups. Formal groups have certain requirements for membership. Apart from formal groups, there are informal groups, an example being friendship groups. In a group, effective and coordinated communication and behavior with other group members is needed in order to achieve common goals. Without effective communication, conflicts between members can occur, and success in achieving common goals can be compromised.

The COVID-19 pandemic brought about a change in behavior in most communities. The Covid-19 pandemic represents a massive global health crisis and requires largescale behaviour change, such as application of social distancing as a vital strategy to slow the pace of the pandemic [8]. This study aims to provide an overview of parenting style and relationship patterns of Chinese community in Tanjungpinang, in the context of Chinese New Year celebrations, which were conducted exactly two months before the COVID-19.

\section{PARENTING STYLE}

Parenting style is conceptualized as a collection of attitudes or patterns of parental authority towards children. Parenting creates an emotional context for the expression of parental behavior [9]. Diana Baumrind explained four basic styles of interaction between parents and children, namely: (a) authoritative parenting, (b) permissive parenting, (c) neglected parenting, and (d) authoritarian parenting [10], [11].
First, authoritative parenting. Parents with authoritative parenting emphasize the individuality of the child but also emphasize social boundaries. Authoritative parents respect the decisions, interests, choices, and personality of children. They not only love and accept children but also demand good behavior. In addition, parents are also firm in maintaining standards. Punishment is carried out in the context of a warm and supportive relationship. Children with authoritative parenting feel safe knowing the demands that are expected of them and that they are loved. Authoritative parenting style combines respect for the individuality of children with efforts to instill social values in children [5].

The second type of parenting is permissive parenting. Permissive parenting emphasizes self-expression. Permissive parents make only a few demands and allow the child to supervise his or her own activities as much as possible. When parents have to make rules, they explain why. They consult with children to decide what rules to make and they rarely punish children. Parents with permissive parenting are warm, uncontrolling, and less demanding [5].

The third parenting style is neglected. Parents with neglected parenting are shown as parents who sometimes, due to stress or depression, focus more on their own needs rather than the needs of their children. This type of parenting is associated with a variety of behavioral disorders in children and adolescents [5].

The fourth parenting style is authoritarian. Authoritarian parenting, according to Baumrind, emphasizes unquestionable control and compliance. Authoritarian parents try to get children to follow set standards of behavior. Parents with authoritarian parenting will punish their children arbitrarily and forcibly for violating established standards of behavior. Parents with this type are more distanced and colder than parents with other parenting styles. Children with authoritarian parents tend to be more dissatisfied, aloof, and distrustful [5].

\section{ECOLOGICAL THEORY}

This theory explains how human development is influenced by various types of environmental systems. The theory of human development proposes that development occurs over time as part of a complex process involving a system of interactions within individuals and between individuals as well as the environmental context in which individuals are a part of [12]. Bronfenbrenner describes children's environment in several environmental levels consisting of: (a) microsystem, (b) mesosystem, (c) exosystem, (d) macrosystem and (e) chronosystem [5]. 


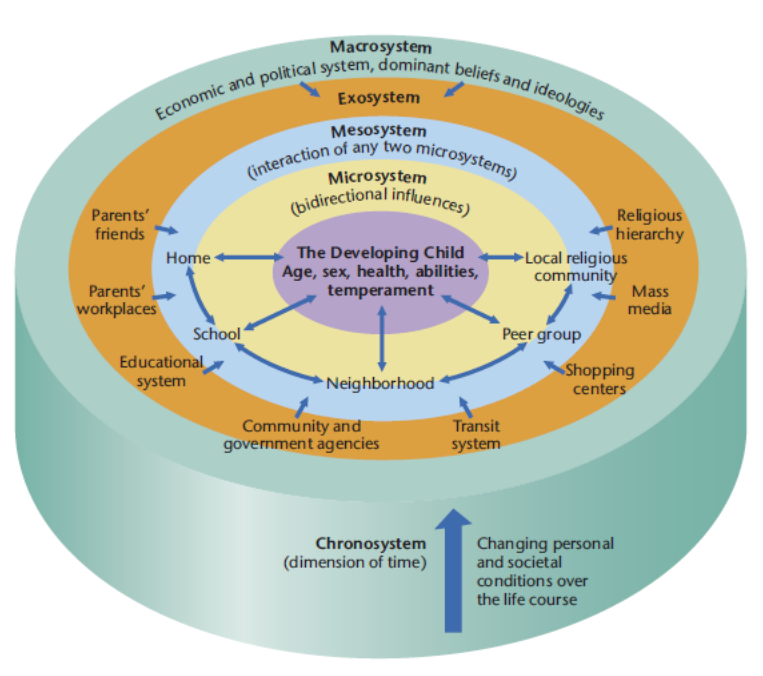

Figure 1 Ecological Systems Model [13]

The most basic ecological level is the microsystem, which includes interactions between individuals. The microsystem level is the everyday environment, such as home, school, work or neighbors. This includes the twoway relationship of children with parents, friends, classmates, and teachers [5].

The next Bronfenbrenner ecological level is the mesosystem, which involves the processes that occur in micro-systems where individuals grow. Microsystem plays a role in activities that can affect a person's development. When something happens in one microsystem, it affects other microsystems. Family and school are the central micro-systems that interact with activities outside of school [12].

Exosystem is the next outer system which includes microsystems in which individuals are involved but not directly. Exosystem affects individual development through other people involved in the individual's life [12]. Macrosystem is defined as a set of beliefs, values, and norms, which are reflected in community organizations, culture, social and socio-cultural [12]. Macrosystem consists of cultural patterns, such as dominant beliefs, ideologies and economic systems and political systems [5]. Macro systems influence developments within and between all other systems and serve as filters influencing how an individual interprets future experiences.

One of the important macrosystems is social class and culture. Social class refers to the economic and educational position of an individual or family in respect to thelarger hierarchy within the society. Culture is defined as a group of values, practices, and beliefs that are specific to certain ethnic groups [12].

The chronosystem is the outermost tier of the Bronfenbrenner model. The chronosystem level involves the time dimension, including change and constancy in people and the environment. This can include changes in family structure, residence, or work, as well as larger cultural changes such as wars and economic cycles such as periods of recession [5].

\section{METHOD}

The study was conducted using a qualitative method, and ethnographic approach. Ethnography is defined as research in which the researcher immerses themselves in a social setting to observe events directly [14]. Data collection was conducted through observation and in-depth interviews.

This research was conducted to coincide with Chinese New Year's Day, from January 23 to 26, 2020. In addition, there was a bazaar held in the context of Chinese New Year celebrations. This event is held regularly once a year. Researchers also conducted research in Pelantar, Pulang Senggarang, and Pasar Kota Lama areas. There are many descendants of Chinese families living in these areas.

The participants of this study were five families living in Tanjungpinang, as well as the community that was involved in the Chinese New Year celebration. The following is the description of the participants who took part in this study. We mention one family member as the main participant who became the spokesperson and source of this research data.

Participant no. 1 is a father (referred to as L), whom is an entrepreneur in Tanjungpinang. He is the second generation residing in Indonesia. L's family consists of father, mother, and two children (boy and girl).

Participant no. 2 is a housewife (referred to as $\mathrm{SH}$ ) whom the research team met at the Bazaar. Mrs. SH's husband is the Head of the RT (Rukun Tetangga) in Tanjungpinang. Mrs. SH has 2 children.

Participant no. 3 is a housewife (referred to as $\mathrm{X}$ ), she has one child studying in Batam. Participant no. 4 is Mrs. Y, a household shop owner, has a son and a daughter, along with grandchildren. Mrs. Y lives with her husband in Tanjungpinang, while her son and daughter live in different cities. Participant no. 5 is a father, with a family who owns a coffee shop whom the Research Team met in Pelantar

\section{FINDINGS}

This research, which was conducted by the research team in Tanjungpinang, found several things, especially regarding parenting styles, as well as the relationship patterns of the Chinese family community in Tanjungpinang.

\subsection{Parenting Style}

The results of observations and interviews with participants showed that although shown in different forms, the parenting styles of the five families that the researchers met were authoritative. The parents applied a balance between control and compassion for their children.

For example, in the participant no. 1's family, Mr. L has a minimum requirement regarding the level of education that his children must achieve, that they must complete bachelor level education. Mr and Mrs L worked hard and had paid for the education of their children. At this point, all their children have completed their Bachelor's degrees, and one 
of the daughters has finished her Master's degree. Although the demands of these parents are high, these demands are balanced with love, understanding, and acceptance for their children, including when their children experience uncomfortable situations.

This family maintains togetherness by getting into the habit of having dinner together. On the eve of Chinese New Year, all family members gather at home, to have dinner together. During meals, families interact with each other and exchange ideas. It is at dinner that parents form and instill family values. Mr. L also introduced values through the stories of important figures. In a subtle way, Mr. L demanded that their children have certain values, but also respect the freedom to make their own choices, and be responsible for their choices. When their children experience difficulties, both parents show acceptance of the children as they are.

Struggle in his childhood made Mr. L tougher as the head of the family, who strongly upholds values, and these values are demanded to also be held by his children

Participant no. 2's family consists of Mrs. SH, her husband, and their two children, a boy and a girl. Mrs. SH is a mother who is very active in organizations in the community, and is one of the annual Bazaar committee.

Participant no. 2 shows different demands and affection from participant no. 1. Participant no. 2, Mrs. SH, did not experience difficult childhood as compared to Mr. L. However, Mrs. SH together with her husband made demands on her children to live up to the values they believed to be good. For example, that education is important, and that the younger generation must be obedient to elders.

Children should not argue with their parents, but children can convey their ideas and thoughts by discussing them with their parents. The parents require their children to always do schoolwork, and limit the use of devices that they see can interfere with their children's learning activities. However, in addition to their demands for achievement in education, Mrs. SH and her husband show great affection and acceptance to their children. One form of affection shown by participant no. 2 to their children is to go on a vacation with them once a year.

A pattern similar to the participant no. 1 and 2's families were shown by the families of participants 3, 4, and 5 . These three families have demands, which were generally in the form of achieving adequate education levels, being respectful towards parents, and helping parents on a daily basis. However, this demand is also balanced with the acceptance of parents towards their children, including the parents' willingness to listen to their children, and to provide comfort when their children need it.

Based on the results of these observations and interviews, it can be concluded that the five families show authoritative parenting style, in which there is a balance between demand and responsiveness to children. On average, all participant families require their children to attain good education, such as completing a bachelor's degree at a university. Despite placing demands on their children, the parents are willing to listen to their children's ideas and aspirations in the form of discussions and other forms of communication. The parents also allow their children to choose their own majors according to their children's interests. This is consistent with authoritative parenting, which emphasizes the individuality of the child but also social boundaries. Parents also respect their children's decisions, interests, choices and personality. They not only love and accept children but also demand good manners [5].

\subsection{Relationship patterns in the community}

The Chinese New Year celebration in Tanjungpinang is special. In other areas such as Jakarta, Yogyakarta, Solo, Tegal, Singkawang, and Manado, in general, the Chinese New Year day is a family day. Community celebrations are generally held in the period leading up to Cap Go Meh, or 15 days after the Chinese New Year day. However, in Tanjungpinang, community celebrations are held to coincide with the change of Chinese calendar. This year, the 2571/2020 Chinese New Year Celebration was held on January 25, 2020.

Through interviews and observations it appears that the relationship between community members tends to be formal and not intimate. Observations were conducted especially during the Bazaar which has been running for one month, and during the Chinese New Year community celebration.

Based on observations during the Bazaar and Chinese New Year celebrations in Tanjungpinang, it appears that the relationship between community members tends to be formal.

The Bazaar is filled with people from all walks of life, but there were not many informal and intimate interactions between shopkeepers and visitors. There was no intimate communication between bazaar visitors either. Everyone acted formally and stuck to their respective duties.

Meanwhile, formal relationships can also be seen during the Chinese New Year community celebration, for example: (a) invitations, (b) seating arrangements, (c) presence of regional officials, (d) stage, and (e) interactions between people at the event. 


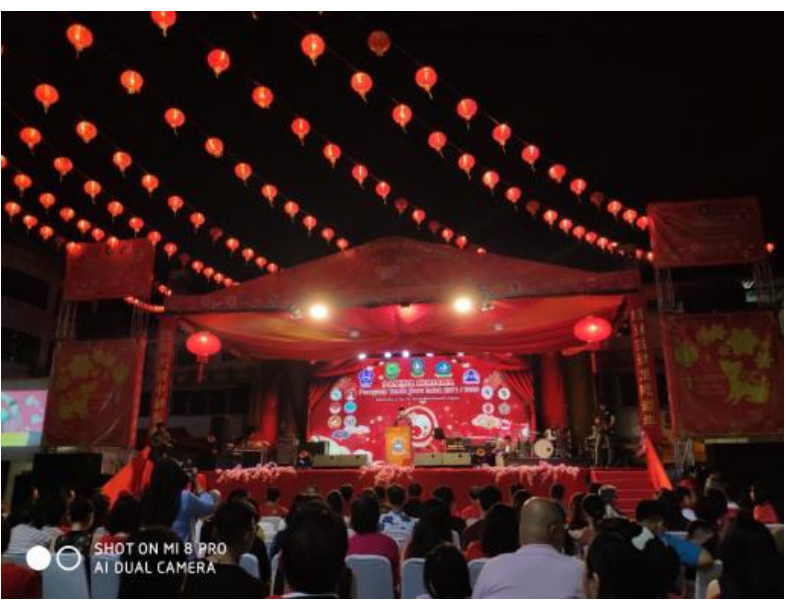

Figure 22020 Chinese New Year celebration event

First, in order to take part in this Chinese New Year celebration, one must already have an invitation. Those who do not have an invitation cannot participate in this event. Second, there are seating arrangements that require attendees to sit according to the number listed in their invitations.

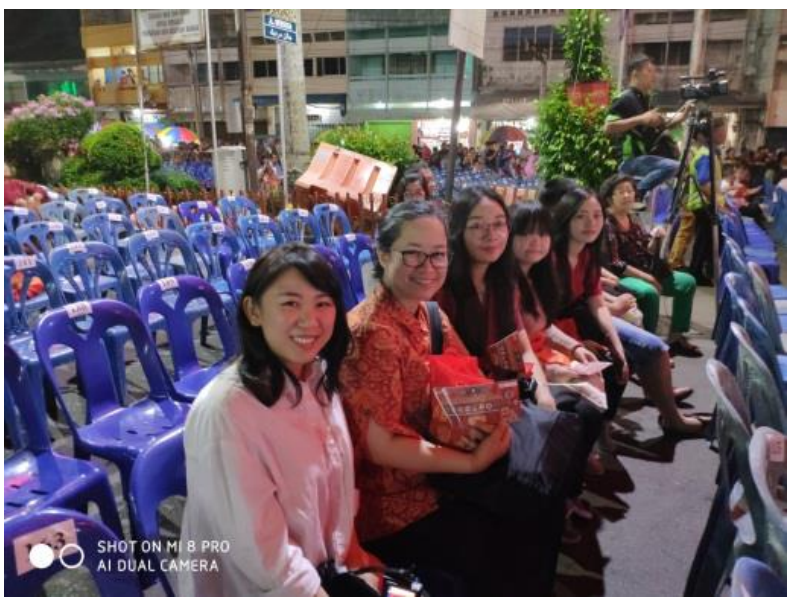

Figure 3 Chinese New Year celebration event with numbers assigned to every seat

Third, this event was attended by local officials who then gave a formal speech. This indicates cooperation with the government. Fourth, there is a stage which is approximately 5 meters away from the front seats. The stage is installed in such a way that there is a distance between the people on the stage and the audience. This stage setting differs from other cities this research took place, at which the distances were closer. Fifth, interaction between visitors in this event is limited. The seating arrangement makes it orderly, but this limits the opportunity for interaction between visitors. It is possible that visitors who know each other cannot gather together, because they have to sit according to their assigned number. The five points above indicate rules that must be obeyed. In regards to theories in social psychology, these characteristics indicate that the type of relationship in this community is formal. There is a requirement to become a member of a formal group [7].

The Chinese New Year community celebration in Tanjungpinang is different from the Chinese New Year celebrations in other areas. The atmosphere in other areas seems more intimate and communal. A familiar atmosphere was seen in the areas that the Research Team had previously studied, namely Solo, Tegal, Cirebon, Yogyakarta, Padang, and Singkawang. Researchers also found interesting interactions between parents and children in this event. At this event, parents tend to supervise and keep their children closer to them. This is different from other research areas. In the Tegal area, for example, during the Cap Go Meh community celebration, parents tend to allow children to explore and enjoy entertainment available around them.

The Chinese New Year community celebration event in Tanjungpinang was realized due to cooperation of various parties, such as the government, educational institutions, youth organizations, and the Tanjungpinang community. The study also found that there is a strong and equal sense of mutual respect among community members.

This respect is evident from the coordination of the organizing committee from various formal organizations in Tanjungpinang. Although each organizing committee comes from different organizations with different vision and mission, each organization can work together to realize the Chinese New Year celebration in Tanjungpinang. The respect and coordination shown by the event committee is in line with a group theory which states that effective communication is needed to avoid misunderstandings. A key factor for effective communication and task performance in a group is the degree to which members feel that they share a common identity [7].

Furthermore, a strong mutual respect was evident from the smooth and safe running of the event despite guests who came from various backgrounds. The guests who attended came from various groups, such as: (a) bureaucracy, (b) community organizations, and (c) local education agencies and (d) the general public.

\subsection{Social Relationship Patterns and Use of Gadgets}

Social relationship patterns show that gadget usage is high among the younger generation, and this can affect social awareness.

During the Chinese New Year celebration, the researchers found several young people who used gadgets throughout the event. Field study found that children have had gadgets since the 5th grade of elementary school. These children use their gadgets to play games and watch Youtube. This is inversely proportional to their parents who are more focused on watching the Chinese New Year celebration. 
This shows that children and parents are busy with their own activities.

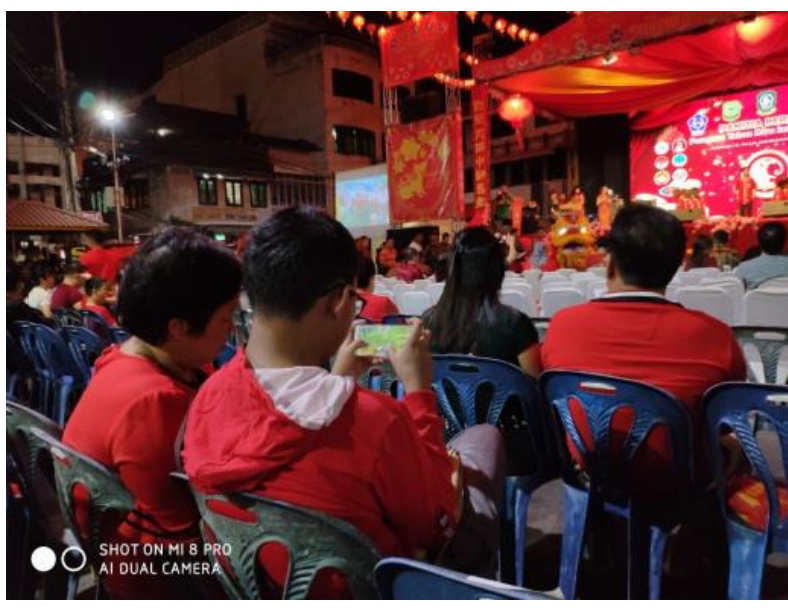

Figure 4 Gadget usage during Chinese New Year Celebration

Children kept playing with their gadgets even during the celebration. This results in a lack of understanding by the children and younger generations of the ongoing social situation, even though this Chinese New Year celebration event was held with the aim of introducing and preserving Chinese culture which is supposed to be entertaining for all ages. There were lion dances, tribal and clan song and dances, and traditional Chinese musical instruments, even modern dance.

Field study found that apart from adopting authoritative parenting, Chinese families in Tanjungpinang also embraced development by allowing gadget use for their children. Gadgets are a tool used for communication. Gadgets when used appropriately can promote relationships between community members.

The use of gadget by the younger generation is expected to become more prevalent during the COVID-19 pandemic. This research was conducted two months before the COVID-19 outbreak in Indonesia. It was found that the younger generation seemed to pay more attention to their gadgets than the social situation that took place around them. The use of gadgets by the younger generation is estimated to be more frequent due to limited direct social interactions, and is replaced by indirect interactions through gadgets.

\subsection{Community Influence on Family and Individual}

All observations and interviews that have been conducted in Tanjungpinang supported the ecological theory of Bronfenbrenner. The behavior of Chinese individuals and communities in Tanjungpinang can be explained by Bronfenbrenner's ecological theory.

At the microsystem level, individual behavior is influenced by their interactions with other family members. In this study, individual behavior is heavily influenced by authoritative parenting. At the mesosystem level, behavior can be explained in the context of interactions between different microsystems, for example, during the celebration of Chinese New Year. Various institutions collaborate with each other, for example, schools, government institutions, local youth institutions, as well as with other various institutions that attended the event. It can be seen that parents also took their children to participate in this event. Parents tend to support and encourage their children when the goals and norms of activities align with family goals [12].

Chinese New Year celebration and Bazaar in Tanjungpinang can serve as a factor at the exosystem level that influence individual behavior. Both events have become a pattern of activities that have been routinely held annually and have become part of the Tanjungpinang City community. This series of celebratory events aims to preserve and introduce Chinese culture to the general community. The Bazaar and the Chinese New Year celebration events indirectly affect the general community, starting from the social and economic structure, providing cultural education as well as providing entertainment for visitors.

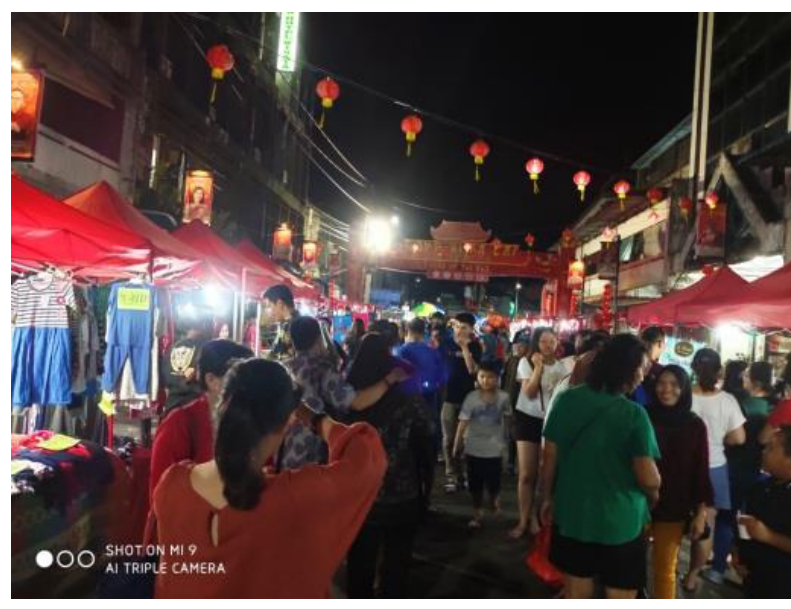

Figure 5 Chinese New Year Bazaar in Tanjungpinang

This event also influenced the different generations of Chinese people in Tanjungpinang. The older generation, such as parents, grew up following this celebration every year. The parents then pass this habit on to the next generation, such as their children, which then becomes a pattern that occurs from generation to generation. Children's exposure to cultural activities can indirectly affect children's development. Children who were brought by their parents can witness various Chinese cultures through a series of shows that take place.

This is in line with the theory which states that Exosystem includes micro systems in which individuals are not directly involved. Exosystem affects individual development through other people involved in the individual's life. One example is how parents can influence their children's activities by introducing their children to activities that parents are familiar with. Thus, children tend 
to participate in the same types of activities their parents participated in when they were children [12].

This research was conducted two months before the COVID-19 pandemic, so that at the macrosystem level, Indonesia was still stable and everything was running normally. Interaction between individuals was still unrestricted, whether directly or indirectly. Furthermore, the economy and politics were stable, and the community and the environment was safe.

The influence of cultural values is also seen in the parenting styles of Chinese families in Tanjungpinang, indicated by parents who prioritize educational aspect. Parents place educational demands on their children to pursue certain levels of education. Despite different demands, all the families that participated in this study prioritized education for their children. This is in accordance with the theory which states that the Macrosystem consists of cultural patterns, such as dominant beliefs, ideologies and economic systems and political systems [5].

This research was conducted in several places such as Tanjungpinang, Senggaran Island, Pelantar, and other areas to get a broader picture of the life of Chinese families in the Riau Islands. At the chronosystem stage the researchers found several interesting facts about the distribution of the Chinese ethnic group in Tanjungpinang. There are various Chinese tribes living in Tanjungpinang, but there are 4 major tribes, namely: (a) Hokkien, (b) Tio Ciu, (c) Hakka and (d) Hainanese. Based on the results of the research, these tribes chose to settle down at locations with similar geographical characteristics to their previous residence in China. In addition, these tribes also brought along with them habits and skills that they used to do in China as a source of income when they settled in Indonesia.

The Hakka tribe inhabits mostly hilly areas in China, so when a Hakka family migrated, the family will choose to live in hilly areas. Most of the families of these tribes would not choose to live in the coastal area. This also affects employment, where many people from the Hakka tribe chose to work manual labor, because they have always been around hills and forests. People from the Hakka tribe lack the skills to become fishermen, because they are used to living in hilly areas.

Meanwhile, many of the Tio Ciu in China live by the sea and work as fishermen. They have expertise in fishing. This affected the Tio Ciu family who had migrated to Tanjungpinang. Just like the previous tribe, this tribe also sought to live in an environment similar to the characteristics of their original place of residence in China. The Tio Ciu tribe chose the Pelantar area when they migrated, which was by the sea. Pelantar is one of the areas in Tanjungpinang which borders the sea. This area is famous for its roads built over the sea.

Apart from the Hakka and Tio Ciu tribes, there are the Hainanese people who have migrated to Tanjungpinang. The Hainanese tribe originated from the island of Hainan in China. The island is abundant with coconut trees, which the Hainanese made into jam. This jam is known as Kaya jam. When the Hainanese migrated to Tanjungpinang, most of them opened coffee shops (kopitiam) and sold Kaya jams. This jam is meant to be consumed with toast.
In addition, many Hainanese have also started businesses that sell home appliances such as ceramic cups. One of the shops the research team visited sold coffee cups. The flower motif on the coffee cup is a flower motif originating from Hainan Island. Based on the description above, according to the chronosystem level that involves the time dimension, namely changes and constancy in people and the environment, this can include changes in family structure, place of residence, work, as well as larger cultural changes such as wars and economic cycles such as recession [5].

\section{CONCLUSION}

Based on the results, it was found that of the five families, despite having different demands and affection, all five of them showed authoritative parenting style. The relationships between community members reflected in the Bazaar and Chinese New Year Celebration in Tanjungpinang were formal, but there was a strong sense of mutual respect between community members. In addition to the two main findings above, the researchers also found that some young people had used gadgets during the event. The use of these gadgets reduces social awareness and understanding. They were unaware of the performances and interactions that took place. The use of these gadgets is expected to increase as a result of the COVID-19 outbreak. There is an influence of the community context on the behavior of Chinese individuals and families in Tanjungpinang and this finding supports the ecological theory put forward by Bronfenbrenner. This can be seen in various levels proposed by Bronfenbrenner, including: (a) microsystem, (b) mesosystem, (c) exosystem, (d) macrosystem and (e) chronosystem.

\section{ACKNOWLEDGMENT}

This work was supported by the Institute for Research and Community Engagement of Universitas Tarumanagara. We would like to thank all participants, including families and individuals who participated in this study. We would also like to thank Mr. FF who gave the opportunity for the research team to join the Chinese New Year Celebration in Tanjungpinang. Lastly, we would like to thank our research assistants (Claudia Fiscarina, Fenny Lusiana, Hartinah Dinata, and Vivien H. Wangi) who helped in this study.

\section{REFERENCES}

[1] T. Susanto, "Selayang Pandang: Sejarah Singkat Kota Tanjungpinang," Pemerintah Kota Tanjungpinang, 2017.

[2] T. Chairani, "Kemeriahan Bazaar Imlek di Kota Lama Tanjungpinang," Dinas Kominfo 
(Diskominfo) Pemerintah Kota Tanjungpinang, Tanjungpinang, 2019.

[3] T. Chairani, "Ratusan Stan Ramaikan Bazar Imlek 2571 di Kota Lama Tanjungpinang," Dinas Kominfo (Diskominfo) Pemerintah Kota Tanjungpinang, Tanjungpinang, 2019.

[4] D. Arman and A. W. Swastiwi, "Menelusuri Jejak Etnis Tionghoa di Tanjungpinang," Kementerian Pendidikan dan Kebudayaan Direkorat Jenderal Kebudayaan Balai Pelestarian Nilai Budaya Kepulauan Riau, 06Feb-2019.

[5] D. E. Papalia, R. D. Feldman, and G. Martorell, Experience Human Development, 12th ed. New York, NY: Mc Graw-Hill, 2012.

[6] T. W. Chan and A. Koo, "Parenting style and youth outcomes in the UK," Eur. Sociol. Rev., vol. 27, no. 3, pp. 385-399, Jun. 2011.

[7] N. R. Branscombe and R. A. Baron, Social Psychology, 14th ed. Pearson Education, Inc, 2017.

[8] J. J. V. Bavel et al., "Using social and behavioural science to support COVID-19 pandemic response," Nature Human Behaviour, vol. 4, no. 5. Nature Research, pp. 460-471, 01May-2020.

[9] C. Leung and S. Tsang Kit Man, "Parenting Style," in Encyclopedia of Quality of Life and Well-Being Research, A. C. Michalos, Ed. Dordrecht: Springer Netherlands, 2014, pp. 4608-4611.

[10] D. Baumrind, "The Influence of Parenting Style on Adolescent Competence and Substance Use," J. Early Adolesc., vol. 11, no. 1, pp. 56-95, Feb. 1991.

[11] D. Baumrind, "The Average Expectable Environment Is Not Good Enough: A Response to Scarr," Child Dev., vol. 64, no. 5, pp. 12991317, Oct. 1993.
[12] A. Ettkal and J. L. Mahoney, "Ecological Systems Theory," in The SAGE Encyclopedia of Out-of-School Learning, K. Peppler, Ed. SAGE Publications, Inc., 2017, pp. 239-241.

[13] M. Cole, S. R. Cole, and J. Boies, The Development of Children. Worth Publishers, 1989.

[14] D. Howwit, Introduction to Qualitative Research Methods in Psychology, 3rd ed., no. 1. United Kingdom, Harlow: Pearson Education, Inc, 2010. 